\title{
Trace Organic Removal during River Bank Filtration for Two Types of Sediment
}

\author{
Victoria Burke ${ }^{1, *}$, Laura Schneider ${ }^{1}$, Janek Greskowiak ${ }^{1}$, Patricia Zerball-van Baar ${ }^{2}$, \\ Alexander Sperlich ${ }^{2}$, Uwe Dünnbier ${ }^{2}$ and Gudrun Massmann ${ }^{1}$
}

1 Working Group Hydrogeology and Landscape Hydrology, Department of Biology and Environmental Sciences, Carl von Ossietzky University of Oldenburg, D-26111 Oldenburg, Germany; laura.schn@web.de (L.S.); janek.greskowiak@uni-oldenburg.de (J.G.); gudrun.massmann@uni-oldenburg.de (G.M.)

2 Berliner Wasserbetriebe, 10864 Berlin, Germany; Patricia.Zerball-Vanbaar@bwb.de (P.Z.-v.B.); Alexander.Sperlich@bwb.de (A.S.); Uwe.Duennbier@bwb.de (U.D.)

* Correspondence: victoria.burke@uni-oldenburg.de; Tel.: +49-441-7984683

Received: 26 October 2018; Accepted: 21 November 2018; Published: 26 November 2018

\begin{abstract}
The process of bank filtration acts as a barrier against many anthropogenic micropollutants, such as pharmaceuticals and industrial products, leading to a substantial improvement of groundwater quality. The performance of this barrier is, however, affected by seasonal influences and subject to significant temporal changes, which have already been described in the literature. Much less is known about spatial differences when considering one field site. In order to investigate this issue, two undisturbed cores from a well-investigated bank filtration field site were sampled and operated in the course of a column study. The ultimate aim was the identification and quantification of heterogeneities with regard to the biodegradation of 14 wastewater derived micropollutants, amongst others acesulfame, gabapentin, metoprolol, oxypurinol, candesartan, and olmesartan. While six of the compounds entirely persisted, eight compounds were prone to degradation. For those compounds that were subject to degradation, degradation rate constants ranged between 0.2 day $^{-1}$ (gabapentin) and 31 day $^{-1}$ (valsartan acid). Further, the rate constants consistently diverged between the distinct cores. In case of the gabapentin metabolite gabapentin-lactam, observed removal rate constants differed by a factor of six between the cores. Experimental data were compared to values calculated according to two structure based prediction models.
\end{abstract}

Keywords: redox sensitivity; micropollutants; oxypurinol; gabapentin

\section{Introduction}

The process of induced bank filtration-defined as the extraction of groundwater near or under a river or lake to induce infiltration from the surface water body [1] —results in recharge of the implicated aquifer on the one hand, but is predominantly intended for water quality improvement. The elimination of suspended solids, particles, bacteria, and viruses due to filtration and the removal of biodegradable compounds contribute to an effective natural attenuation of the bank filtrate [2]. The significance of bank filtration as a measure of managed aquifer recharge is clarified by the fraction of bank filtrate in drinking water supplies of individual countries in Europe summarized in Dillon et al. [3] ranging from $7 \%$ in the Netherlands, $9 \%$ in Germany, 25\% in Switzerland, to 50\% in Slovakia and Hungary.

Especially in densely populated areas, bank filtration is used within the concept of a partly closed water cycle. Given these conditions, the infiltrated surface water is to some extent wastewater influenced as it acts as receiving water for wastewater treatment plant effluents. Hence, wastewater 
treatment plant effluents represent point-sources for organic micropollutants, as the removal of these compounds is often incomplete during treatment [4]. Accordingly, a large number of studies previously reported on elevated concentrations of organic micropollutants, such as pharmaceuticals and personal care products, industrial agents, or artificial sweeteners, in treated wastewater (e.g., [5-8]). Besides potential negative impacts on the aquatic ecosystem [9], these compounds may also influence the groundwater quality and eventually the drinking water quality by entering the groundwater body via bank filtration.

A number of studies have shown that many wastewater-derived organic micropollutants are (at least to some extent) attenuated during the process of bank filtration (e.g., [10-13]). As proven in the course of field and lab studies, the transport- and degradation behavior of organic micropollutants during subsurface flow highly depends on the prevailing (hydrochemical) conditions along the flow path. Parameters identified to be of special importance in that context are temperature [14,15], $\mathrm{pH}$ value [16], redox conditions [13,17,18], sediment characteristics (i.e., organic carbon content [19]), and availability of primary substrate in the infiltrating water $[20,21]$.

Some of the above-mentioned parameters are highly transient during bank filtration due to seasonal variations in the source water and also closely interrelated [11,22]. Accordingly, the removal efficiency during bank filtration undergoes temporal fluctuations, which was demonstrated for example by Greskowiak et al. [17].

Though the temporal variability was repeatedly proven, investigations on the spatial variation of the attenuation efficiency during bank filtration are sparse. It is evident, that removal rates notably differ between individual field sites. Take the analgesic diclofenac as an example: a compilation of biodegradation rate constants published by Greskowiak et al. [23] revealed rate constants observed at bank filtration sites ranging between 0.0025 day $^{-1}$ and 17 day $^{-1}$. Apart from the knowledge of differences between individual locations, the question of heterogeneities at one field site is rather unclear. In order to fill this gap, the presented study covers column experiments simulating the process of bank filtration using two undisturbed cores, which were sampled from the same bank filtration site (Berlin Tegel, Berlin, Germany), but differed with regard to vegetation cover.

The study included a set of 14 human pharmaceuticals from different pharmacological classes discharged by a wastewater treatment plant nearby the sampling site and hence present in the respective source water also used for the experiments. Among them the anticonvulsants gabapentin, carbamazepine, primidone, and the respective transformation products gabapentin-lactam, 10,11-dihydro-10,11-dihydroxy-carbamazepine (DiOH-CBZ) and phenylethylmalonamide (PEMA). Another anticonvulsant present in source water and thus considered during this study was pregabalin.

Antihypertensive medications belong to the most prescribed therapeutic groups in human medicines, as hypertension is a serious public health problem [24] and one of the main risks leading to death in the world [25]. This study considered the antihypertensives metoprolol, candesartan and olmesartan. Whereas metoprolol is one of the classic beta-blockers, candesartan and olmesartan belong to a relatively new generation of antihypertension medications called angiotensin II receptor blockers (ARBs). The market launch of the first ARB (losartan) was 1995 and followed by highly increasing prescription rates $[26,27]$. So far, only a few studies dealt with the entry into the environment and the environmental behavior of these two sartans. Gurke et al. [28] reported on candesartan concentrations $>1 \mu \mathrm{g} \mathrm{L}^{-1}$ in treated wastewater effluents. Bayer et al. [29] detected candesartan and olmesartan in wastewater influenced surface waters with maximum concentrations of $1.1 \mu \mathrm{g} \mathrm{L}^{-1}$ and $2.2 \mu \mathrm{g} \mathrm{L}^{-1}$, respectively.

As transformation product evolving from different sartans (e.g., valsartan, olmesartan, candesartan) during wastewater treatment, valsartan acid was also examined during this study. It was previously shown to occur in elevated concentrations in wastewater treatment plant effluents, surface water, groundwater, and even in tap water [30-32]. Recently, its biodegradation in pilot-scale granular activated carbon filters for drinking water treatment was shown [33]. However, information published on the environmental behavior of valsartan acid is sparse. 
The list of compounds is completed by the phenazone-type metabolite formylaminoantipyrine (FAA), the artificial sweetener acesulfame and oxypurinol, which is the active metabolite of the widely prescribed anti-gout agent allopurinol. Whereas the first-mentioned compounds were already subject of various studies [14,34-36], oxypurinol, in comparison, has been insufficiently studied. Funke et al. [37] detected oxypurinol in surface water samples in concentrations up to $23 \mu \mathrm{g} \mathrm{L}^{-1}$ and even in drinking water in concentrations up to $0.4 \mu \mathrm{g} \mathrm{L}^{-1}$ caused by the discharge of treated wastewater. However, oxypurinol can efficiently be removed by adsorption onto activated carbon [33].

The overall objectives of the study were to quantitatively characterize the degradation behavior of the investigated compounds during bank filtration and to identify and quantify spatial variations in degradation. A comparison of the observed data with two different quantitative structure-activity relationships (QSAR) approaches targets an assessment according to existing models.

\section{Materials and Methods}

\subsection{Core Sampling}

Two undisturbed sediment cores were collected at a bank filtration site in Berlin, Germany, where groundwater is abstracted by the local water supplier for drinking water production (Latitude: 52.575384, Longitude: 13.262819). The study site located at 'Lake Tegel' is well investigated and described due to former research activities focusing on the fate and transport of organic micropollutants during bank filtration $[11,38,39]$. In order to identify local heterogeneities in micropollutant removal related to different sediment properties, one sediment core was taken from a sandy section of the lakeshore (hereinafter referred to as core A) and another one from a reed-covered shore section (hereinafter referred to as core B). Accordingly, these cores showed considerable differences regarding the fraction of sedimentary organic carbon. Information on the sediment properties of the cores are to be found in Section 3.1.

During core drilling, tubes with an inner diameter of $0.08 \mathrm{~m}$ were pushed into the sediment by application of the vibrocorer technique. Subsequently, tube and sediment core were drawn using a combination of tripod and pulley. For a detailed description of the sampling procedure refer to Burke et al. [14]. Thus, sediment cores of a length of $1.02 \mathrm{~m}$ (core A) and $0.81 \mathrm{~m}$ (core B) were retrieved and incorporated into the experimental setup described in Section 2.2. In order to determine the sedimentary organic carbon fraction via loss of ignition (combustion of sample aliquots at $430{ }^{\circ} \mathrm{C}$ for $3 \mathrm{~h}$ ), a second core was sampled in parallel by using a common inliner-system. This parallel core was also used for sieving in order to characterize the grain size distribution.

\subsection{Experimental Setup}

The experimental setup used within this study was adapted from Burke et al. [14]. Briefly, each column was equipped with oxygen probes and rhizome samplers in different depths, enabling periodic $\mathrm{O}_{2}$ measurements and sampling in order to define the hydrochemical conditions along the flow path (Figure 1). The sample ports of core A were placed in infiltration depths of 0, 3, 5, 13, 23, 38, $51,76,96$, and $102 \mathrm{~cm}$. The sample ports of core B were installed at infiltration depth of $0,3,5,14,24$, $38,51,74$, and $81 \mathrm{~cm}$.

Turned upside down, the columns were operated in an upward mode, thus preventing the entrapment of air and ensuring fully saturated conditions. Each column was connected to a peristaltic pump injecting surface water sampled from Lake Tegel as column influent solution in order to design the experimental conditions as site specific as possible. The surface water quality of Lake Tegel is influenced by treated wastewater, as it is part of a surface water system receiving wastewater treatment plant effluents [40], establishing a semi-closed urban water cycle. Thus, all compounds targeted during this study were present in the lake water and not spiked during the course of the experiment. Information on the composition of the column inlet, averaged according to the duration of the experiment, are listed in the Supplementary Material (Table S1). 
Conservative tracer tests conducted with bromide revealed longitudinal dispersion coefficients, $\mathrm{D}_{1}$, of $3.2 \times 10^{-7} \mathrm{~m}^{2} \mathrm{~s}^{-1}$ and $6.12 \times 10^{-7} \mathrm{~m}^{2} \mathrm{~s}^{-1}$ and mean pore water velocities, $\mathrm{v}$, of $1.3 \times 10^{-5} \mathrm{~m}$ $\mathrm{s}^{-1}$ and $1.2 \times 10^{-5} \mathrm{~m} \mathrm{~s}^{-1}$ for cores $\mathrm{A}$ and core $\mathrm{B}$, respectively. Consequently, hydraulic retention times of $22 \mathrm{~h}$ (core A) and $19 \mathrm{~h}$ (core B) were calculated. Temperature measurements throughout the study yielded an average of $21^{\circ} \mathrm{C}$.

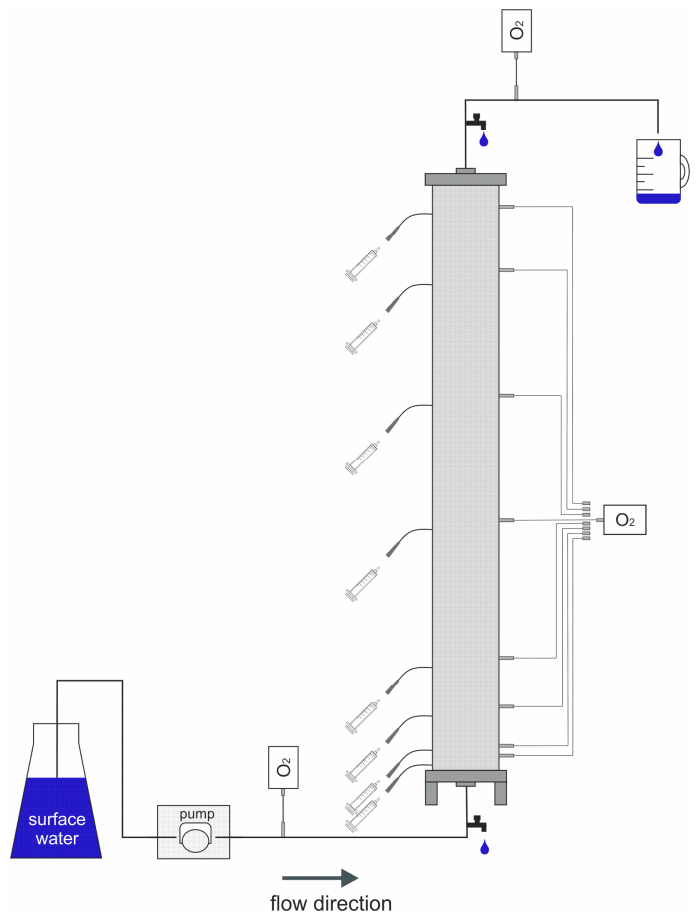

Figure 1. Experimental setup—adapted from Burke et al. [14].

\subsection{Sampling and Sample Analysis}

In the course of a conditioning period, the cores were operated for approximately six months in order to reach steady state conditions regarding the redox system. During this time, oxygen measurements and sample collection considering the entire depth profiles were performed once a week. Samples were analyzed for nitrate $\left(\mathrm{NO}_{3}{ }^{-}\right)$, manganese $\left(\mathrm{Mn}^{2+}\right)$, iron $\left(\mathrm{Fe}^{2+}\right)$ and sulfate $\left(\mathrm{SO}_{4}{ }^{2-}\right)$. Biweekly, additional samples for the determination of dissolved organic carbon (DOC) and $\mathrm{pH}$ value were abstracted at the in- and outlets of the columns.

The conditioning period was followed by the experimental period consisting of three individual sampling events with an interval of one week between the respective events. Apart from the aforementioned parameters, samples intended for trace organic analysis were abstracted from all sampling ports.

Samples meant for analysis of $\mathrm{NO}_{3}{ }^{-}$and $\mathrm{SO}_{4}{ }^{2-}$ were filtered using $0.45 \mu \mathrm{m}$ cellulose acetate filters (Sartorius Minisart ${ }^{\circledR}$, Göttingen, Germany) and immediately analyzed by ion chromatography with a Basic IC plus (Metrohm, Filderstadt, Germany) according to DIN EN ISO 14911. $\mathrm{Fe}^{2+}$ and $\mathrm{Mn}^{2+}$ were determined photometrically using a compact photometer (PF-12, Macherey-Nagel, Düren, Germany). DOC samples were filtered using $0.7 \mu \mathrm{m}$ glass fibre filters (Whatman, Maidstone, UK). Previously, sampling vessels and filters were combusted for five hours at $400{ }^{\circ} \mathrm{C}$ in order to remove possible residues of organic substances. Samples were acidified with hydrochlorid acid to a $\mathrm{pH}$ of 2 and stored dark and $\operatorname{cool}\left(\sim 4{ }^{\circ} \mathrm{C}\right)$ until further processing. Analysis was carried out by application of high temperature combustion at a total organic carbon (TOC) analyzer (Shimadzu, Kyoto, Japan). For details on this method refer to Wurl [41]. 
Samples intended for trace organic analysis were filled into glass vessels and stored at $-18{ }^{\circ} \mathrm{C}$ until further processing. Analysis was carried out in the laboratories of the Berliner Wasserbetriebe. Chromatographic separation was carried out on an ACQUITY UPLC HSS T3 column $(100 \mathrm{~mm} \times 2.1 \mathrm{~mm} ; 1.8 \mu \mathrm{m})$ (Waters $\mathrm{GmbH}$, Milford, MA, USA) using an ACQUITY Ultra Performance HPLC-system (Waters $\mathrm{GmbH}$ ). The column oven was maintained at $40{ }^{\circ} \mathrm{C}$. The mobile phase consisting of water (containing $0.05 \%$ acetic acid) and methanol with a linear gradient from $5 \%$ to $95 \%$ methanol in $8 \mathrm{~min}$ at a flow rate of $0.4 \mathrm{~mL} / \mathrm{min}$. The samples were kept at $5{ }^{\circ} \mathrm{C}$ in the autosampler. Samples were analyzed directly with an injection volume of $50 \mu \mathrm{L}$. The mass spectrometry was performed on a Xevo TQ-S mass spectrometer (Waters $\mathrm{GmbH}$ ). Masslynx software was used for data acquisition and analysis (Waters $\mathrm{GmbH}$ ).

Ionization was attained using an electrospray ionization (ESI) source in positive and negative ion mode. The ESI source was operated with a desolvation temperature of $600{ }^{\circ} \mathrm{C}$. The desolvation gas and cone gas were $1000 \mathrm{~L} \mathrm{~h}^{-1}$ and $150 \mathrm{~L} \mathrm{~h}^{-1}$, respectively. Nebulizer gas pressure was set by 6 bar, and the capillary voltage used was $3.5 \mathrm{~V}$ in positive mode and $2 \mathrm{~V}$ in negative mode. Target compounds were identified in the selected reaction monitoring (SRM) mode recording two transitions between precursor ions and the two most abundant product ions. Details on certain transitions, including cone voltages and collision energies applied, as well as retention times and limits of quantification (LOQs) are presented in the Supplementary Material (Table S2).

\subsection{Data Evaluation}

The concentration depth profiles presented within Section 3.2 display arithmetic mean values and standard deviations calculated from the individual experimental runs $(n=3)$. Values below the limit of quantification (LOQ) were set to LOQ/2. Degradation rate constants were fitted assuming 1st order degradation. After 6 months of adaption phase to the respective input concentrations, sorption was assumed to be negligible and disregarded.

In order to describe the prevailing redox conditions along the flow path, the classification scheme proposed by Regnery et al. [42] was slightly modified. Oxygen, nitrate, dissolved manganese and iron as well as sulfide served as redox indicators. Redox zones were classified as oxic, suboxic and anoxic, whereby anoxic conditions were further specified as nitrate reducing, iron/manganese reducing or sulfidic. The criteria used within this classification scheme are listed in Table 1.

Table 1. Classification scheme used for redox indication.

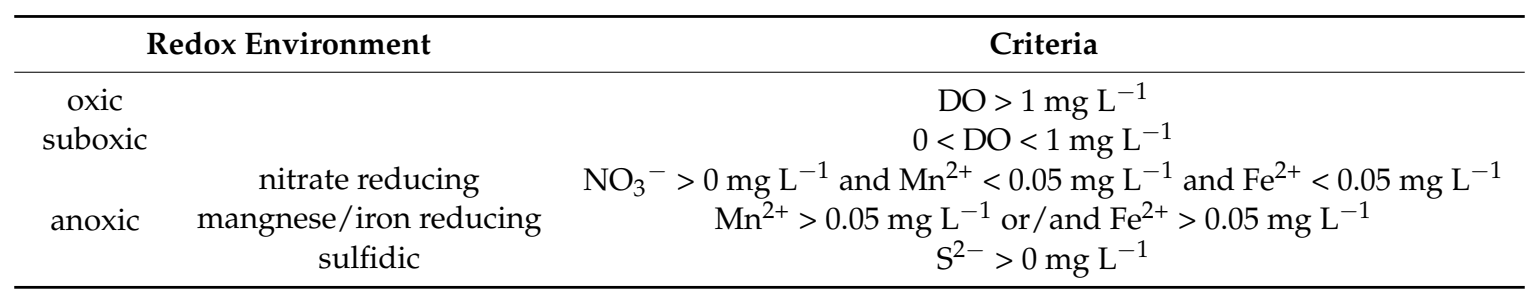

\section{Results and Discussion}

\subsection{Sediment Properties and Hydrochemical Conditions}

Both cores used in the course of this study consisted of sandy sediments, where fine sand is the dominating fraction (Figure 2). The fraction of medium to coarse sand tends to increase with depth along core A, with a maximum of $40 \%$ observed at the bottom of the core. With regard to core B, the fraction of medium to coarse sand varies between 6 and 39\%. Except for a single part in the middle of core A $(60-70 \mathrm{~cm})$, where the silt fraction accounts $4 \%$, the amount of silt is in general negligibly small $(<1 \%)$. 
core $\mathbf{A}$ fractions of grain size (\%)
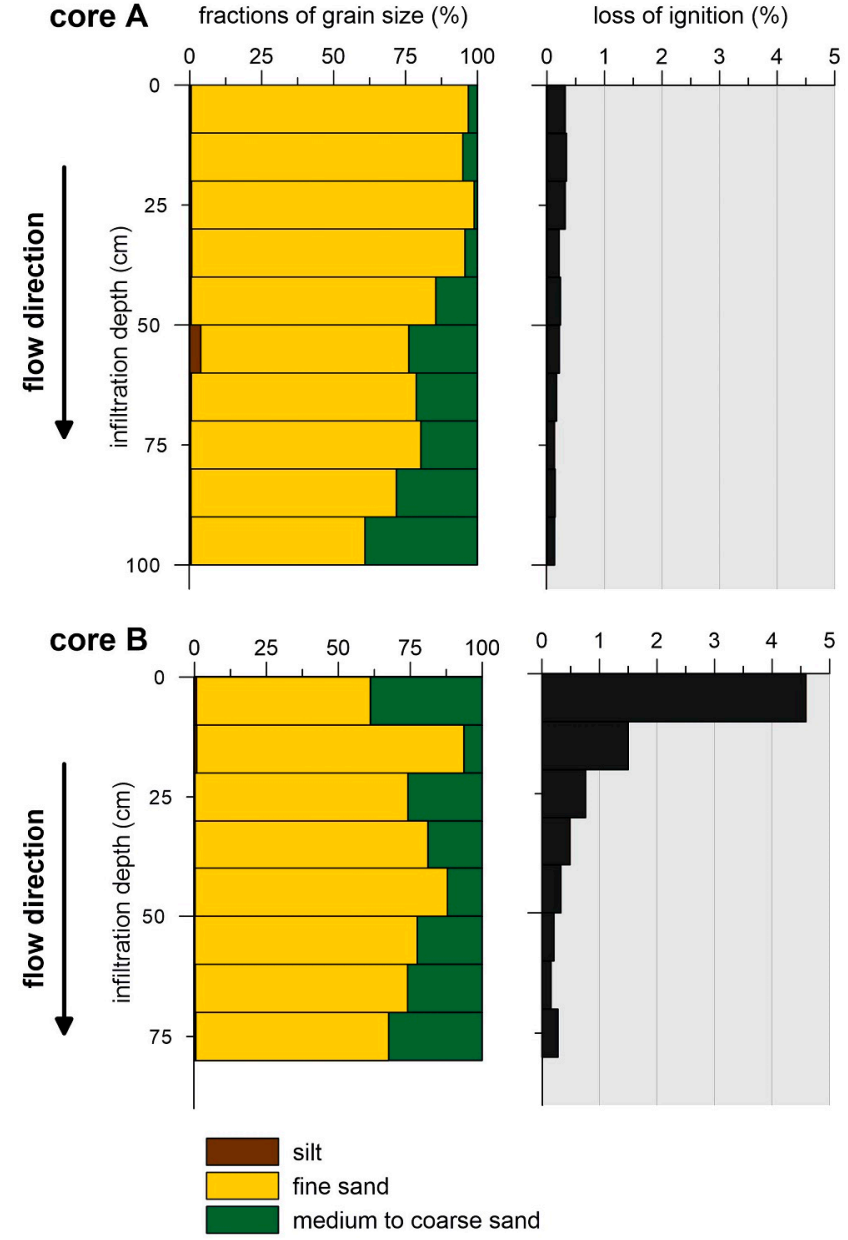

redox conditions
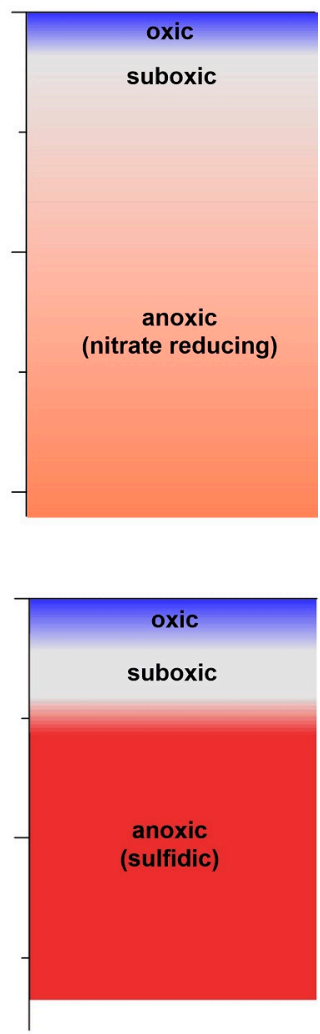

Figure 2. Information on sediment properties (fractions of grain sizes at the left; amount of particulate organic carbon (POC) in the middle) and hydrochemical conditions (at the right) observed along core A (upper part) and core B (lower part). With increasing infiltration depth (from top to bottom) the redox milieu changes from oxic (indicated by blue colours) to suboxic (indicated by grey colors) to anoxic (orange = manganese reducing; red $=$ sulfidic).

The content of particulate organic carbon (POC) revealed differences between the two cores. While along core A nearly no variations in POC content over depth appeared, an elevated POC content was detected for the upper part of core B, where values decreased from $4.5 \%$ within the first $10 \mathrm{~cm}$-which is 10 fold of the core A in the same depth-to $0.8 \%$ in a depth of $30 \mathrm{~cm}$. The lower part of core $\mathrm{B}$ resembles the counterpart of core $\mathrm{A}$.

For the description of the hydrochemical conditions along the flow path, we focused on $\mathrm{pH}$, DOC concentration as well as on the redox relevant parameters described in Section 2.4, since these are strongly influencing the degradation behavior of organic micropollutants. The column influent solutions for both, core $\mathrm{A}$ and core $\mathrm{B}$, were similar regarding $\mathrm{pH}$ value (8.2-8.3) and DOC concentration (7.2-7.3 $\mathrm{mg} \mathrm{L}^{-1}$ ). Along the flow path, $\mathrm{pH}$ values slightly decreased to 7.7 along core $\mathrm{A}$ and to 7.2 along core $\mathrm{B}$. As it acts as primary source for the microbial community, also DOC concentrations dropped to $5.4 \mathrm{mg} \mathrm{L}^{-1}$ (core A) and $6.0 \mathrm{mg} \mathrm{L}^{-1}$ (core B).

Fundamental differences were observed with regard to the development of distinct redox zones. In both columns a thin oxic zone $(\sim 8-10 \mathrm{~cm})$ at the inlet of the column was followed by a thin suboxic zone $(\sim 10-15 \mathrm{~cm})$. At further depth, the main part of core A was characterized by nitrate reducing conditions, as $\mathrm{NO}_{3}{ }^{-}$concentrations decreased from $9.1 \mathrm{mg} \mathrm{L}^{-1}$ to $5.7 \mathrm{mg} \mathrm{L}^{-1}$ and neither $\mathrm{Mn}^{2+}$ nor $\mathrm{Fe}^{2+}$ were observed in notable concentrations. In contrast, core B originating from the reed-covered 
section became highly reducing at an infiltration depth of about $23 \mathrm{~cm}$. This was indicated by increased $\mathrm{S}^{2-}$ concentrations of up to $0.4 \mathrm{mg} \mathrm{L}^{-1}$.

\subsection{Fate of Organic Micropollutants}

\subsubsection{Persistent Compounds}

Six compounds including carbamazepine, candesartan, olmesartan, primidone, as well as the transformation products DiOH-CBZ and PEMA did not show attenuation when passing through the column, since concentrations measured in the column outlet were similar to those measured in the column inflow solution (see Figure S1 in the Supplementary Material). The fact that persistence prevailed in both columns is an indication for the general persistence of these compounds in the aquatic environment, apparently independent of the prevailing hydrochemical conditions and sediment composition.

In case of carbamazepine the environmental persistence has been frequently pointed out (e.g., [43-45]). The poor biodegradability is accompanied by a low tendency to sorb onto soils and sediment (e.g., [46,47]), pointing towards its high environmental relevance and ability to enter various aquatic compartments including groundwater. $\mathrm{DiOH}-\mathrm{CBZ}$, known as the predominant human metabolite evolving from carbamazepine and frequently detected in wastewater treatment plant effluents [48,49], likewise persisted along the flow path at concentrations around $0.5 \mu \mathrm{g} \mathrm{L}^{-1}$.

In lab-scaled sewage treatment plants olmesartan and candesartan were shown to be rather poorly degradable with total elimination percentages $<20 \%$ [29]. Similar to our results, Hellauer et al. [50] found candesartan and olmesartan to be biologically persistent in a column system simulating bank filtration conditions. In the same study, the process of ozonation led to an efficient removal of both compounds. Further, Khan and Nicell [51] expected candesartan to be highly mobile and persistent and suggested its prioritization for further studies.

Primidone and its metabolite PEMA were detected in rather small concentrations of $7 \mathrm{ng} \mathrm{L}^{-1}$ in the surface water used as column influent solution, and-independent of the prevailing redox conditions-no removal was observed along the flow path. The environmental persistence of primidone was already pointed out by other authors in the course of field studies (e.g., [11,52]) and lab studies (e.g., [21,53]). Although the number of studies on the environmental behavior of the primidone metabolite PEMA is small, its poor biodegradability has been revealed by Hass et al. [52] and Nham et al. [54].

\subsubsection{Reactive Compounds}

Due to high consumption rates, as well as largely unaffected passage through the human body and persistence during wastewater treatment $[44,55]$, the artificial sweetener acesulfame is generally detected at elevated concentrations in treated wastewater $[56,57]$ and therefore used as an indicator for wastewater influenced surface waters [58,59] and groundwater [60,61]. Presuming a low sorption affinity and recalcitrance to microbial degradation, acesulfame has formerly been proposed as an ideal anthropogenic marker $[45,55,62]$. However, other previous studies revealed that-under certain conditions-acesulfame is actually prone to microbial degradation $[14,50,63]$. Thereby, acesulfame degradation is largely affected by (i) temperature, (ii) redox conditions, and (iii) biodegradable carbon content [64]. This is supported by our findings, as acesulfame was attenuated under oxic conditions with degradation rate constants of 14.6 day $^{-1}$ (core A) and 10.4 day $^{-1}$ (core B), and under suboxic conditions $\left(\lambda=2\right.$ day $\left.^{-1}\right)$, but persisted under anoxic conditions (Figure 3a). According to Kahl et al. [64], first evidences questioning the recalcitrance of acesulfame came up in 2014. Based on their findings the same authors hypothesized, that acesulfame degrading species evolved during the last few years-for example, due to horizontal gene transfer.

The phenazone type metabolite FAA has formerly been stated to behave redox dependent $[34,65]$. This was also proven during this study, as fast degradation was recognized for the oxic zone while 
FAA persisted under anoxic conditions (Figure 3b). Degradation rate constants observed under oxic conditions were 24.7 day $^{-1}$ (core A) and 7.8 day $^{-1}$ (core B), which are higher than those published elsewhere [23]. However, rate constants of similar magnitude (5.7 day ${ }^{-1}$ and 1.4 day $\left.^{-1}\right)$ have already been noticed under oxic conditions within sandy columns $[14,66]$.
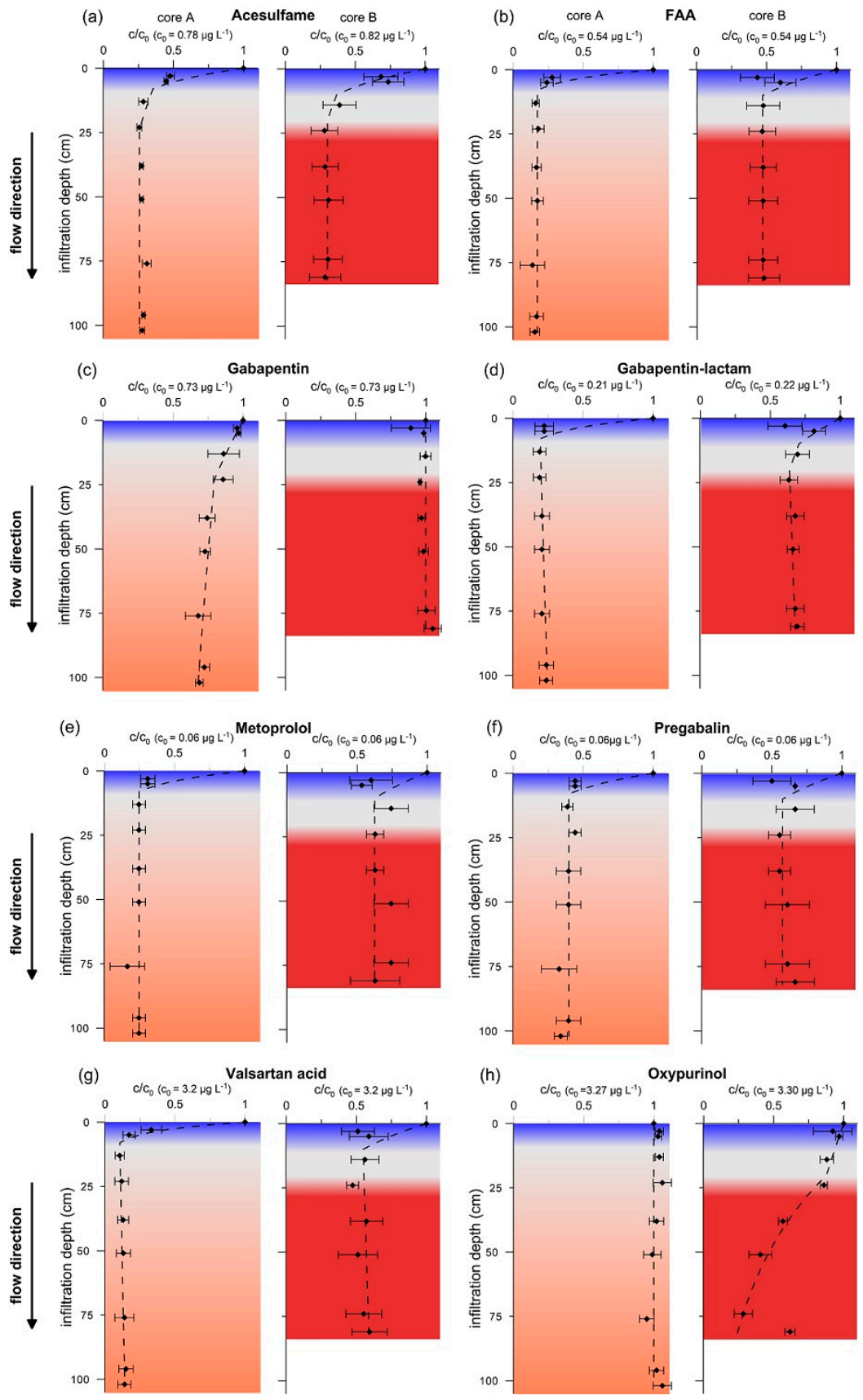

Figure 3. Concentration depth profiles (core A to the left, core B to the right) observed for (a) acesulfame, (b) FAA, (c) gabapentin, (d) gabapentin-lactam, (e) metoprolol, (f) pregabalin, (g) valsartan acid, and (h) oxypurinol. Black circles indicate arithmetic mean values of measured concentrations $(n=3)$ and standard deviations are given by error bars. Removal curves (dashed lines) were created assuming 1st order degradation. The colored background indicates the redox conditions prevalent in the respective part of the column as presented in Figure 2 (blue $=$ oxic, grey $=$ suboxic, orange $/ \mathrm{red}=$ anoxic). The concentrations are presented here as $c / c_{0}$, i.e., normalized to the inlet concentration $\mathrm{c}_{0}$ (shown in brackets). 
A similar picture - characterized by an efficient removal within the upper oxic zone paired with persistence within the remaining suboxic to anoxic part of the column-emerges for metoprolol, pregabalin and valsartan acid (Figure 3e-g). Based on field data, Nödler et al. [31] suggested valsartan acid to behave persistent during bank filtration. However, evaluating the data for valsartan acid of this study yielded the highest degradation rate constant of all compounds $\left(31.5 \mathrm{day}^{-1}\right)$, corresponding to a half-life time of $0.5 \mathrm{~h}$ (core A). In accordance, Hellauer et al. [50] found valsartan acid to be efficiently attenuated after aeration of a test system, while persistence was noticed in an anoxic reference system.

With regard to metoprolol, for which degradation rate constants of 19.7 day $^{-1}$ (core A) and 4.9 day $^{-1}$ (core B) have been observed, our results concur with results reported by other authors, who found a strong redox dependency of metoprolol degradation by means of laboratory experiments [18,67], and also confirm our previous findings [66].

The anticonvulsant gabapentin behaved different along the distinct cores-while the concentration decreased along core A with degradation rate constants of 1.1 day $^{-1}$ in the upper (oxic to suboxic) part and 0.2 day $^{-1}$ in the lower (anoxic) part, persistence was observed along core B (Figure 3c). Hence, the availability of oxygen does not seem to be the controlling factor for gabapentin degradation. These findings differ from those reported by Henning et al. [68] and Hellauer et al. [50], who observed by means of batch and column experiments, respectively, a redox dependent degradation of gabapentin with enhanced removal under aerobic conditions. Since one major difference between both cores is the organic carbon content, which is higher in core B, low carbon contents may favor gabapentin removal. However, by investigating the influence of particular organic carbon on oxygen consumption and attenuation of organic trace compounds, Filter et al. [19] detected neither a distinct impact of the carbon content nor any correlation with the prevailing redox regime. Indications for biodegradation of gabapentin in GAC fixed-bed and tertiary filtration systems have also been found in pilot-scale studies on advanced water and wastewater treatment steps $[33,69,70]$. Further studies for clarification are needed here.

Gabapentin-lactam, the quantitatively most relevant transformation product evolving from Gabapentin [68], showed enhanced attenuation under oxic conditions whereas the concentration remained constant under reducing conditions (Figure 3d). The degradation rate constants obtained were 23.0 day $^{-1}$ for core A and 3.6 day $^{-1}$ for core B. These results share similarities with those of Henning et al. [68], who described also a redox dependent degradation of gabapentin-lactam, even though the reported degradation rate constants of 0.06 day $^{-1}$ were clearly lower.

The attenuation pattern of oxypurinol appeared to be quite different. While persistence was noticed within core $\mathrm{A}$, decreasing concentrations along core $\mathrm{B}$ were detected. The degradation rate constants ranged from $0.7 \mathrm{day}^{-1}$ in the upper part to $2.2 \mathrm{day}^{-1}$ in the lower part. Hence, oxypurinol was more efficiently attenuated under strongly reducing (sulfidic) conditions. By investigating its degradation during managed aquifer recharge, Hellauer et al. [71] found oxypurinol to be persistent during two meters of infiltration under oxic conditions.

By comparing the degradation rate constants observed during this study as shown in Figure 4, it becomes evident that highest removal rates mostly appeared under oxic conditions (blue bars). Four compounds, namely FAA, metoprolol, pregabalin and valsartan acid, where solely degraded under oxic conditions, while acesulfame and gabapentin-lactam also were prone to degradation under suboxic conditions. Deviating from that, the removal of oxypurinol and gabapentin seems not primarily to be controlled by the redox environment, as oxypurinol concentration decreased only along core B while gabapentin concentrations only decreased along core A.

Further, it is apparent from Figure 4 that degradation rate constants within the upper, oxic zone observed considering core A (blue, solid bars) are systematically higher than those observed in core B (blue, striped bars). Highest discrepancies appeared for gabapentin-lactam, for which the removal within the upper (oxic) part of core A was 6 times larger than in the upper (oxic) part of core B. By looking at the sediment characteristics, the main evident difference is the content of organic carbon determined by the loss of ignition, as it is by factor 10 higher in the upper zone of core $\mathrm{B}$ than of core $\mathrm{A}$ 
(Figure 2). Thus, it seems reasonable that the organic carbon content of the sediment influenced the degradation processes. Consistently, Kahl et al. [64] suggested the removal of acesulfame to be most efficient when the availability of biodegradable organic carbon is low. However, during investigations the influence of a compost layer on the attenuation of organic micropollutants, Schaffer et al. [72] observed an enhanced degradation when levels of biodegradable dissolved organic carbon were higher. Since this relation remains unclear, further research needs to be done.

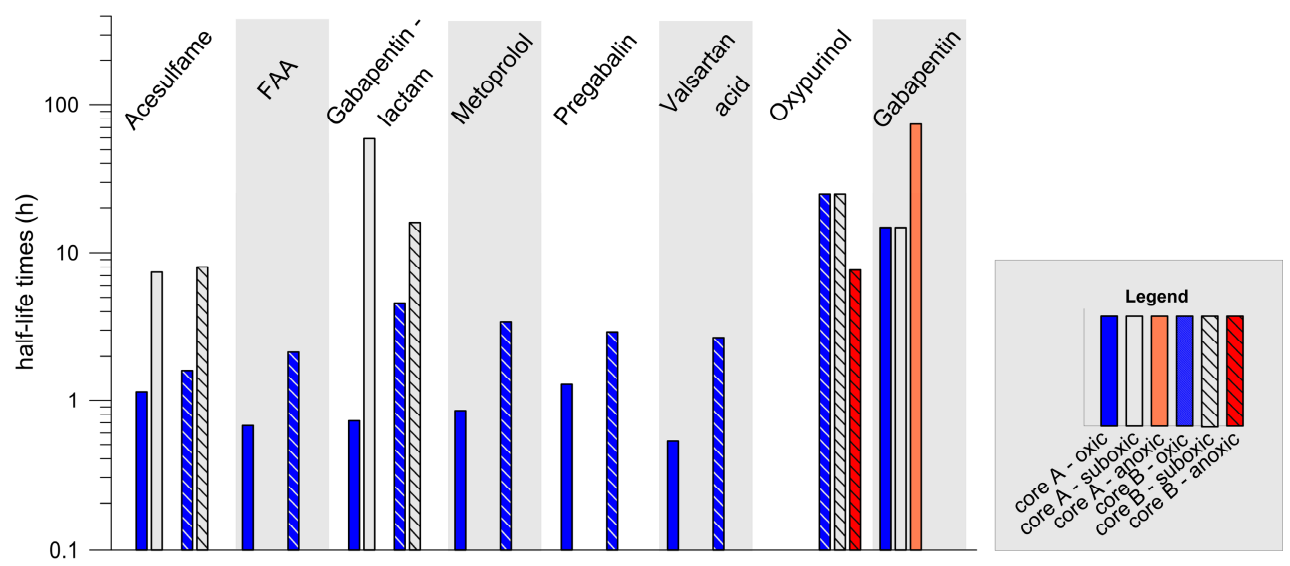

Figure 4. Compilation of observed half-life times (hours) along core A (solid filled bars) and as well as along core B (striped bars) under distinct redox conditions. FAA: formylaminoantipyrine.

\subsection{Comparison with Recent QSAR Approaches}

In order to classify the degradation rate constants observed during this study in relation to existing quantitative structure activity relation models, two QSAR models were picked and rates calculated accordingly and plotted against experimental findings (Figure 5). Firstly, the degradation expert survey BIOWIN 4 from the EPI Suite ${ }^{\mathrm{TM}}$ package (United States Environmental Protection Agency, Washington, DC, USA) [73] was used, which calculates time required for primary degradation, i.e., the change in molecular structure resulting in the formation of a new compound. Secondly, the predictive multi-linear regression model published by Bertelkamp et al. [74] was applied since it focusses especially on bank filtration data. Due to the fact that both models account for degradation under oxic conditions, only data derived from the upper, oxic layer of the columns were compared.

The BIOWIN 4 output indicates the degradation probability of a compound by means of half-life categories (hours, hours-days, days, days-weeks, weeks, weeks-months, months, and recalcitrant). Most of the target compounds investigated during this study, namely acesulfame, FAA, gabapentin-lactam, metoprolol and oxypurinol end up in the category 'days-weeks' in BIOWIN 4, which, after EPI Suite ${ }^{\mathrm{TM}}$, is converted to a degradation rate constant of 0.08 day $^{-1}$. Gabapentin is grouped in the category 'days', which is equivalent to a degradation rate constant of 0.29 day $^{-1}$. The comparison shows that the BIOWIN 4 half-lives are generally larger than those obtained experimentally, hence degradation is faster in the cores. This could be expected, since the data base used for this primary degradation survey primarily includes studies on well defined batch experiments in the absence of sediment. However, reactions at the water-sediment interface are of special importance considering physical and biological processes [75]. Additionally, it was repeatedly shown that the first decimeters of infiltration during bank filtration are highly reactive $[14,76,77]$, leading to comparably high removal rates in this study.

Based on data from a column study with material from a riverbank filtration site and considering a set of 31 organic micropollutants, Bertelkamp et al. [74] derived a multi-linear regression model for predicting their degradation during bank filtration. Applying their model to compounds that behaved reactive during this study revealed degradation rate constants between 1.8 and 4.1 day $^{-1}$. Even though the calculated values are also lower than the experimental data, the deviations are obviously lower 
and data range in a similar order of magnitude. Hence, the model Bertelkamp et al. [74] calibrated for a specific field site was not fully able to predict the compounds behavior of the Berlin site considered in this study, but could have been used for first approximations. However, taking into account the variability in removal rates detected during this study between two cores from the same field site-one can roughly estimate the difficulties that still exist regarding the development of a holistic model aiming at predicting the degradation behavior of organic micropollutants in the aquatic environment.

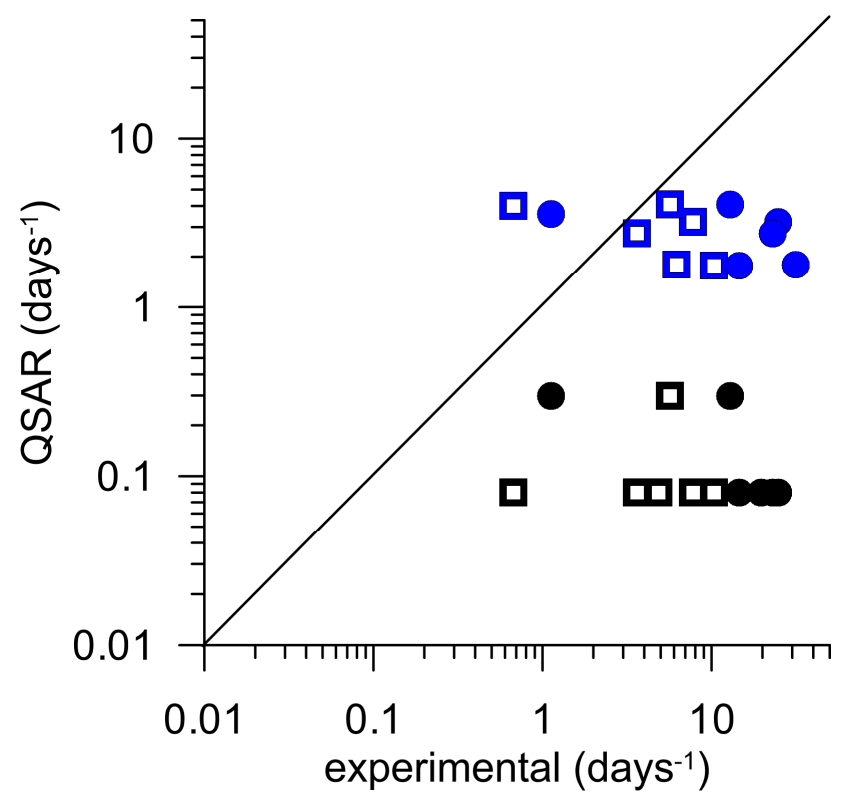

Figure 5. Comparison of data determined experimentally in core A (circles) and core B (rectangles) with data calculated according to Bertelkamp et al. ([74], blue) and the BIOWIN 4 model ([73], black).

\section{Conclusions}

The compounds acesulfame, FAA, gabapentin, gabapentin-lactam, metoprolol, pregabalin, valsartan acid, and oxypurinol are subject to primary degradation under certain conditions during bank filtration. Observed degradation rate constants ranged between $0.2 \mathrm{day}^{-1}$ and $31.4 \mathrm{day}^{-1}$, resulting in half-life times between 3 days and $0.5 \mathrm{~h}$, respectively. Compared to other investigations on the degradation behavior of organic micropollutants these rates are relatively high [23] and may tend to represent removal under most favorable conditions (i.e., in terms of oxygen availability, elevated temperatures, and the grade of nutrient availability). Moreover, our data documents the high reactivity of the initial part of the infiltration flow path, i.e., the lake base.

Hydrochemical conditions and removal patterns observed in the columns indicated notable differences between two cores from the same field site. Although the distance between the sampled cores was only a few meters, (completely) different redox conditions and concentration depth profiles of the organic trace compounds developed. The largest difference in compound removal was found for gabapentin-lactam, which was less degraded by a factor of six in one core compared to another. Since one major difference between the cores was the content of POC, we hypothesize that compound removal was more efficient where the carbon content was low. In order to confirm this assumption a systematic study on this issue is needed. It became obvious, that a robust characterization of a field site, which is intended to be used for process-oriented investigations, requires a closed network of sampling points.

The comparison of experimental data with two structure based prediction models elucidated that-due to the complex interaction of influencing parameters-it is still highly challenging to assess the biodegradation of organic micropollutants under environmental conditions based on compound 
specific properties. Moreover, reactions at the sediment-water interface are of central importance with regard to predictive models.

Supplementary Materials: The following are available online at http:/ / www.mdpi.com/2073-4441/10/12/1736/ s1, Table S1: Information on the water composition of the lake water used as column inlet (averaged over the duration of the experiment, $\mathrm{n}=8$ ), Table S2: Compilation of details describing the analytical method used for trace pollutant analysis (UHPLC-MSMS), Figure S1: Concentration depth profiles observed for compounds that behaved persistent during this study.

Author Contributions: Conceptualization, G.M., U.D., V.B., and J.G.; formal analysis, V.B. and P.Z.-v.B.; investigation, L.S. and V.B.; writing-original draft preparation, V.B. and P.Z.-v.B.; writing-review and editing, J.G., A.S., U.D. and G.M.; supervision, G.M.; project administration, V.B., G.M. and A.S.

Funding: This research was funded by the Berlin Water Company.

Acknowledgments: We would like to thank Britta Drude, Nina Gnuschke, Jessica Schnitger and Ulrike Kücks for practical assistance. Moreover the MPI research group 'Marine Geochemistry' is acknowledged for performing DOC analyses. We kindly acknowledge Helmo Nicolai from the Institute for Chemistry and Biology of the Marine Environment (ICBM) for helping us with the instrumentation used for core drilling.

Conflicts of Interest: The authors declare no conflict of interest.

\section{References}

1. Dillon, P. Future management of aquifer recharge. Hydrogeol. J. 2005, 13, 313-316. [CrossRef]

2. Hiscock, K.M.; Grischek, T. Attenuation of groundwater pollution by bank filtration. J. Hydrol. 2002, 266, 139-144. [CrossRef]

3. Dillon, P.; Stuyfzand, P.; Grischek, T.; Lluria, M.; Pyne, R.D.G.; Jain, R.C.; Bear, J.; Schwarz, J.; Wang, W.; Fernandez, E.; et al. Sixty years of global progress in managed aquifer recharge. Hydrogeol. J. 2018. [CrossRef]

4. Luo, Y.; Guo, W.; Ngo, H.H.; Nghiem, L.D.; Hai, F.I.; Zhang, J.; Liang, S.; Wang, X.C. A review on the occurrence of micropollutants in the aquatic environment and their fate and removal during wastewater treatment. Sci. Total Environ. 2014, 473-474, 619-641. [CrossRef] [PubMed]

5. Vieno, N.; Tuhkanen, T.; Kronberg, L. Elimination of pharmaceuticals in sewage treatment plants in Finland. Water Res. 2007, 41, 1001-1012. [CrossRef] [PubMed]

6. Bartelt-Hunt, S.L.; Snow, D.D.; Damon, T.; Shockley, J.; Hoagland, K. The occurrence of illicit and therapeutic pharmaceuticals in wastewater effluent and surface waters in Nebraska. Environ. Pollut. 2009, 157, 786-791. [CrossRef] [PubMed]

7. Kasprzyk-Hordern, B.; Dinsdale, R.M.; Guwy, A.J. The removal of pharmaceuticals, personal care products, endocrine disruptors and illicit drugs during wastewater treatment and its impact on the quality of receiving waters. Water Res. 2009, 43, 363-380. [CrossRef] [PubMed]

8. Gros, M.; Petrovic, M.; Ginebreda, A.; Barcelo, D. Removal of pharmaceuticals during wastewater treatment and environmental risk assessment using hazard indexes. Environ. Int. 2010, 36, 15-26. [CrossRef] [PubMed]

9. Schwarzenbach, R.P.; Escher, B.I.; Fenner, K.; Hofstetter, T.B.; Johnson, C.A.; von Gunten, U.; Wehrli, B. The challenge of micropollutants in aquatic systems. Science 2006, 313, 1072-1077. [CrossRef] [PubMed]

10. Kovacevic, S.; Radisic, M.; Lausevic, M.; Dimkic, M. Occurrence and behavior of selected pharmaceuticals during riverbank filtration in The Republic of Serbia. Environ. Sci. Pollut. Res. 2017, 24, 2075-2088. [CrossRef]

11. Henzler, A.F.; Greskowiak, J.; Massmann, G. Modeling the fate of organic micropollutants during river bank filtration (Berlin, Germany). J. Contam. Hydrol. 2014, 156, 78-92. [CrossRef] [PubMed]

12. Hamann, E.; Stuyfzand, P.J.; Greskowiak, J.; Timmer, H.; Massmann, G. The fate of organic micropollutants during long-term/long-distance river bank filtration. Sci. Total Environ. 2016, 545, 629-640. [CrossRef] [PubMed]

13. Maeng, S.K.; Ameda, E.; Sharma, S.K.; Grutzmacher, G.; Amy, G.L. Organic micropollutant removal from wastewater effluent-impacted drinking water sources during bank filtration and artificial recharge. Water Res. 2010, 44, 4003-4014. [CrossRef] [PubMed]

14. Burke, V.; Greskowiak, J.; Asmuss, T.; Bremermann, R.; Taute, T.; Massmann, G. Temperature dependent redox zonation and attenuation of wastewater-derived organic micropollutants in the hyporheic zone. Sci. Total Environ. 2014, 482, 53-61. [CrossRef] [PubMed] 
15. Trinh, T.; van den Akker, B.; Coleman, H.M.; Stuetz, R.M.; Drewes, J.E.; Le-Clech, P.; Khan, S.J. Seasonal variations in fate and removal of trace organic chemical contaminants while operating a full-scale membrane bioreactor. Sci. Total Environ. 2016, 550, 176-183. [CrossRef] [PubMed]

16. Gulde, R.; Helbling, D.E.; Scheidegger, A.; Fenner, K. pH-Dependent Biotransformation of Ionizable Organic Micropollutants in Activated Sludge. Environ. Sci. Technol. 2014, 48, 13760-13768. [CrossRef] [PubMed]

17. Greskowiak, J.; Prommer, H.; Massmann, G.; Nutzmann, G. Modeling seasonal redox dynamics and the corresponding fate of the pharmaceutical residue phenazone during artificial recharge of groundwater. Environ. Sci. Technol. 2006, 40, 6615-6621. [CrossRef]

18. Bertelkamp, C.; Verliefde, A.R.D.; Schoutteten, K.; Vanhaecke, L.; Bussche, J.; Singhal, N.; van der Hoek, J.P. The effect of redox conditions and adaptation time on organic micropollutant removal during river bank filtration: A laboratory-scale column study. Sci. Total Environ. 2016, 544, 309-318. [CrossRef]

19. Filter, J.; Jekel, M.; Ruhl, A.S. Impacts of Accumulated Particulate Organic Matter on Oxygen Consumption and Organic Micro-Pollutant Elimination in Bank Filtration and Soil Aquifer Treatment. Water 2017, 9, 12. [CrossRef]

20. Li, D.; Alidina, M.; Drewes, J.E. Role of primary substrate composition on microbial community structure and function and trace organic chemical attenuation in managed aquifer recharge systems. Appl. Microbiol. Biotechnol. 2014, 98, 5747-5756. [CrossRef]

21. Alidina, M.; Li, D.; Ouf, M.; Drewes, J.E. Role of primary substrate composition and concentration on attenuation of trace organic chemicals in managed aquifer recharge systems. J. Environ. Manag. 2014, 144, 58-66. [CrossRef]

22. Massmann, G.; Greskowiak, J.; Duennbier, U.; Zuehlke, S.; Knappe, A.; Pekdeger, A. The impact of variable temperatures on the redox conditions and the behaviour of pharmaceutical residues during artificial recharge. J. Hydrol. 2006, 328, 141-156. [CrossRef]

23. Greskowiak, J.; Hamann, E.; Burke, V.; Massmann, G. The uncertainty of biodegradation rate constants of emerging organic compounds in soil and groundwater-A compilation of literature values for 82 substances. Water Res. 2017, 126, 122-133. [CrossRef]

24. Whelton, P.K.; He, J.; Appel, L.J.; Cutler, J.A.; Havas, S.; Kotchen, T.A.; Roccella, E.J.; Stout, R.; Vallbona, C.; Winston, M.C.; et al. Primary prevention of hypertension: Clinical and public health advisory from The National High Blood Pressure Education Program. JAMA 2002, 288, 1882-1888. [CrossRef]

25. Murray, C.J.L.; Lopez, A.D. Evidence-based health policy-Lessons from the global burden of disease study. Science 1996, 274, 740-743. [CrossRef]

26. Stafford, R.S.; Monti, V.; Furberg, C.D.; Ma, J. Long-term and short-term changes in antihypertensive prescribing by office-based physicians in the United States. Hypertension 2006, 48, 213-218. [CrossRef]

27. Campbell, N.R.C.; McAlister, F.A.; Brant, R.; Levine, M.; Drouin, D.; Feldman, R.; Herman, R.; Zarnke, K.; Canadian Hypertension Eval, P. Temporal trends in anti hypertensive drug prescriptions in Canada before and after introduction of the Canadian Hypertension Education Program. J. Hypertens. 2003, 21, 1591-1597. [CrossRef]

28. Gurke, R.; Rossmann, J.; Schubert, S.; Sandmann, T.; Rossler, M.; Oertel, R.; Fauler, J. Development of a SPE-HPLC-MS/MS method for the determination of most prescribed pharmaceuticals and related metabolites in urban sewage samples. J. Chromatogr. B 2015, 990, 23-30. [CrossRef]

29. Bayer, A.; Asner, R.; Schussler, W.; Kopf, W.; Weiss, K.; Sengl, M.; Letzel, M. Behavior of sartans (antihypertensive drugs) in wastewater treatment plants, their occurrence and risk for the aquatic environment. Environ. Sci Pollut. Res. 2014, 21, 10830-10839. [CrossRef]

30. Letzel, T.; Bayer, A.; Schulz, W.; Heermann, A.; Lucke, T.; Greco, G.; Grosse, S.; Schüssler, W.; Sengl, M.; Letzel, M. LC-MS screening techniques for wastewater analysis and analytical data handling strategies: Sartans and their transformation products as an example. Chemosphere 2015, 137, 198-206. [CrossRef]

31. Nödler, K.; Hillebrand, O.; Idzik, K.; Strathmann, M.; Schiperski, F.; Zirlewagen, J.; Licha, T. Occurrence and fate of the angiotensin II receptor antagonist transformation product valsartan acid in the water cycle-A comparative study with selected beta-blockers and the persistent anthropogenic wastewater indicators carbamazepine and acesulfame. Water Res. 2013, 47, 6650-6659. [CrossRef]

32. Hermes, N.; Jewell, K.S.; Wick, A.; Ternes, T.A. Quantification of more than 150 micropollutants including transformation products in aqueous samples by liquid chromatography-tandem mass spectrometry using scheduled multiple reaction monitoring. J. Chromatogr. A 2018, 1531, 64-73. [CrossRef] 
33. Sperlich, A.; Harder, M.; Zietzschmann, F.; Gnirss, R. Fate of trace organic compounds in Granular Activated Carbon (GAC) adsorbers for drinking water treatment. Water 2017, 9. [CrossRef]

34. Massmann, G.; Duennbier, U.; Heberer, T.; Taute, T. Behaviour and redox sensitivity of pharmaceutical residues during bank filtration-Investigation of residues of phenazone-type analgesics. Chemosphere 2008, 71, 1476-1485. [CrossRef]

35. Bichler, A.; Muellegger, C.; Brünjes, R.; Hofmann, T. Quantification of river water infiltration in shallow aquifers using acesulfame and anthropogenic gadolinium. Hydrol. Process. 2015. [CrossRef]

36. Storck, F.R.; Skark, C.; Remmler, F.; Brauch, H.J. Environmental fate and behavior of acesulfame in laboratory experiments. Water Sci. Technol. 2016, 74, 2832-2842. [CrossRef]

37. Funke, J.; Prasse, C.; Eversloh, C.L.; Ternes, T.A. Oxypurinol-A novel marker for wastewater contamination of the aquatic environment. Water Res. 2015, 74, 257-265. [CrossRef]

38. Heberer, T.; Mechlinski, A.; Fanck, B.; Knappe, A.; Massmann, G.; Pekdeger, A.; Fritz, B. Field studies on the fate and transport of pharmaceutical residues in bank filtration. Ground Water Monit. Remediat. 2004, 24, 70-77. [CrossRef]

39. Massmann, G.; Sueltenfuss, J.; Duennbier, U.; Knappe, A.; Taute, T.; Pekdeger, A. Investigation of groundwater a residence times during bank filtration in Berlin: Multi-tracer approach. Hydrol. Process. 2008, 22, 788-801. [CrossRef]

40. Schimmelpfennig, S.; Kirillin, G.; Engelhardt, C.; Nutzmann, G.; Dunnbier, U. Seeking a compromise between pharmaceutical pollution and phosphorus load: Management strategies for Lake Tegel, Berlin. Water Res. 2012, 46, 4153-4163. [CrossRef]

41. Wurl, O. Practical Guidelines for the Analysis of Seawater; CRC Press: Boca Raton, FL, USA; Taylor \& Francis Group: Abingdon-on-Thames, UK, 2009.

42. Regnery, J.; Wing, A.D.; Alidina, M.; Drewes, J.E. Biotransformation of trace organic chemicals during groundwater recharge: How useful are first-order rate constants? J. Contam. Hydrol. 2015, 179, 65-75. [CrossRef]

43. Fenz, R.; Blaschke, A.P.; Clara, M.; Kroiss, H.; Mascher, D.; Zessner, M. Monitoring of carbamazepine concentrations in wastewater and groundwater to quantify sewer leakage. Water Sci. Technol. 2005, 52, 205-213. [CrossRef]

44. Scheurer, M.; Storck, F.R.; Graf, C.; Brauch, H.J.; Ruck, W.; Lev, O.; Lange, F.T. Correlation of six anthropogenic markers in wastewater, surface water, bank filtrate, and soil aquifer treatment. J. Environ. Monit. 2011, 13, 966-973. [CrossRef]

45. Foolad, M.; Ong, S.L.; Hu, J. Transport of sewage molecular markers through saturated soil column and effect of easily biodegradable primary substrate on their removal. Chemosphere 2015, 138, 553-559. [CrossRef]

46. Calisto, V.; Esteves, V.I. Adsorption of the antiepileptic carbamazepine onto agricultural soils. J. Environ. Monit. 2012, 14, 1597-1603. [CrossRef]

47. Yu, L.; Fink, G.; Wintgens, T.; Melina, T.; Ternes, T.A. Sorption behavior of potential organic wastewater indicators with soils. Water Res. 2009, 43, 951-960. [CrossRef]

48. Kaiser, E.; Prasse, C.; Wagner, M.; Broder, K.; Ternes, T.A. Transformation of oxcarbazepine and human metabolites of carbamazepine and oxcarbazepine in wastewater treatment and sand filters. Environ. Sci. Technol. 2014, 48, 10208-10216. [CrossRef]

49. Brezina, E.; Prasse, C.; Meyer, J.; Mückter, H.; Ternes, T.A. Investigation and risk evaluation of the occurrence of carbamazepine, oxcarbazepine, their human metabolites and transformation products in the urban water cycle. Environ. Pollut. 2017, 225, 261-269. [CrossRef]

50. Hellauer, K.; Mergel, D.; Ruhl, A.S.; Filter, J.; Hubner, U.; Jekel, M.; Drewes, J.E. Advancing sequential managed aquifer recharge technology (SMART) using different intermediate oxidation processes. Water 2017, 9, 14. [CrossRef]

51. Khan, U.; Nicell, J. Human health relevance of pharmaceutically active compounds in drinking water. AAPS J. 2015, 17, 558-585. [CrossRef]

52. Hass, U.; Duennbier, U.; Massmann, G. Occurrence and distribution of psychoactive compounds and their metabolites in the urban water cycle of Berlin (Germany). Water Res. 2012, 46, 6013-6022. [CrossRef]

53. Lin, K.D.; Bondarenko, S.; Gan, J. Sorption and persistence of wastewater-borne psychoactive and antilipidemic drugs in soils. J. Soils Sediments 2011, 11, 1363-1372. [CrossRef]

54. Nham, H.T.T.; Greskowiak, J.; Hamann, E.; Meffe, R.; Hass, U.; Massmann, G. Long-term transport behavior of psychoactive compounds in sewage-affected groundwater. Grundwasser 2016, 21, 321-332. [CrossRef] 
55. Buerge, I.J.; Buser, H.R.; Kahle, M.; Muller, M.D.; Poiger, T. Ubiquitous occurrence of the artificial sweetener acesulfame in the aquatic environment: An ideal chemical marker of domestic wastewater in groundwater. Environ. Sci. Technol. 2009, 43, 4381-4385. [CrossRef]

56. Scheurer, M.; Brauch, H.-J.; Lange, F.T. Analysis and occurrence of seven artificial sweeteners in German waste water and surface water and in soil aquifer treatment (SAT). Anal. Bioanal. Chem. 2009, 394, 1585-1594. [CrossRef]

57. Li, S.L.; Ren, Y.H.; Fu, Y.Y.; Gao, X.S.; Jiang, C.; Wu, G.; Ren, H.Q.; Geng, J.J. Fate of artificial sweeteners through wastewater treatment plants and water treatment processes. PLoS ONE 2018, 13, e16. [CrossRef]

58. Li, Z.; Sobek, A.; Radke, M. fate of pharmaceuticals and their transformation products in four small European rivers receiving treated wastewater. Environ. Sci. Technol. 2016, 50, 5614-5621. [CrossRef]

59. Müller, C.E.; Gerecke, A.C.; Alder, A.C.; Scheringer, M.; Hungerbühler, K. Identification of perfluoroalkyl acid sources in Swiss surface waters with the help of the artificial sweetener acesulfame. Environ. Pollut. 2011, 159, 1419-1426. [CrossRef]

60. Yang, Y.Y.; Zhao, J.L.; Liu, Y.S.; Liu, W.R.; Zhang, Q.Q.; Yao, L.; Hu, L.X.; Zhang, J.N.; Jiang, Y.X.; Ying, G.G. Pharmaceuticals and personal care products (PPCPs) and artificial sweeteners (ASs) in surface and ground waters and their application as indication of wastewater contamination. Sci. Total Environ. 2018, 616, 816-823. [CrossRef]

61. Spoelstra, J.; Senger, N.D.; Schiff, S.L. Artificial sweeteners reveal septic system effluent in rural groundwater. J. Environ. Qual. 2017, 46, 1434-1443. [CrossRef]

62. Robertson, W.D.; Van Stempvoort, D.R.; Solomon, D.K.; Homewood, J.; Brown, S.J.; Spoelstra, J.; Schiff, S.L. Persistence of artificial sweeteners in a 15-year-old septic system plume. J. Hydrol. 2013, 477, 43-54. [CrossRef]

63. Castronovo, S.; Wick, A.; Scheurer, M.; Nodler, K.; Schulz, M.; Ternes, T.A. Biodegradation of the artificial sweetener acesulfame in biological wastewater treatment and sandfilters. Water Res. 2017, 110, 342-353. [CrossRef]

64. Kahl, S.; Kleinsteuber, S.; Nivala, J.; van Afferden, M.; Reemtsma, T. Emerging biodegradation of the previously persistent Artificial Sweetener Acesulfame in biological wastewater treatment. Environ. Sci. Technol. 2018, 52, 2717-2725. [CrossRef]

65. Burke, V.; Richter, D.; Hass, U.; Duennbier, U.; Greskowiak, J.; Massmann, G. Redox-dependent removal of 27 organic trace pollutants: Compilation of results from tank aeration experiments. Environ. Earth Sci. 2014, 71, 3685-3695. [CrossRef]

66. Burke, V.; Greskowiak, J.; Grunenbaum, N.; Massmann, G. Redox and temperature dependent attenuation of twenty organic micropollutants-A systematic column study. Water Environ. Res. 2017, 89, 155-167. [CrossRef]

67. de Wilt, A.; He, Y.; Sutton, N.; Langenhoff, A.; Rijnaarts, H. Sorption and biodegradation of six pharmaceutically active compounds under four different redox conditions. Chemosphere 2018, 193, 811-819. [CrossRef]

68. Henning, N.; Kunkel, U.; Wick, A.; Ternes, T.A. Biotransformation of gabapentin in surface water matrices under different redox conditions and the occurrence of one major TP in the aquatic environment. Water Res. 2018, 137, 290-300. [CrossRef]

69. Altmann, J.; Rehfeld, D.; Trader, K.; Sperlich, A.; Jekel, M. Combination of granular activated carbon adsorption and deep-bed filtration as a single advanced wastewater treatment step for organic micropollutant and phosphorus removal. Water Res. 2016, 92, 131-139. [CrossRef]

70. Altmann, J.; Sperlich, A.; Jekel, M. Integrating organic micropollutant removal into tertiary filtration: Combining PAC adsorption with advanced phosphorus removal. Water Res. 2015, 84, 58-65. [CrossRef]

71. Hellauer, K.; Karakurt, S.; Sperlich, A.; Burke, V.; Massmann, G.; Hubner, U.; Drewes, J.E. Establishing sequential managed aquifer recharge technology (SMART) for enhanced removal of trace organic chemicals: Experiences from field studies in Berlin, Germany. J. Hydrol. 2018, 563, 1161-1168. [CrossRef]

72. Schaffer, M.; Kroger, K.F.; Nodler, K.; Ayora, C.; Carrera, J.; Hernandez, M.; Licha, T. Influence of a compost layer on the attenuation of 28 selected organic micropollutants under realistic soil aquifer treatment conditions: Insights from a large scale column experiment. Water Res. 2015, 74, 110-121. [CrossRef]

73. United States Environmental Protection Agency. Estimation Programs Interface Suite ${ }^{\mathrm{TM}}$ for Microsoft ${ }^{\circledR}$ Windows, v 4.1; United States Environmental Protection Agency: Washington, DC, USA, 2012. 
74. Bertelkamp, C.; Verliefde, A.; Reynisson, J.; Singhal, N.; Cabo, A.; De Jonge, M.; van der Hoek, J.P. A predictive multi-linear regression model for organic micropollutants, based on a laboratory-scale column study simulating the river bank filtration process. J. Hazard. Mater. 2016, 304, 502-511. [CrossRef]

75. Santschi, P.; Hohener, P.; Benoit, G.; Buchholtztenbrink, M. Chemical processes at the sediment water interface. Mar. Chem 1990, 30, 269-315. [CrossRef]

76. Heberer, T.; Massmann, G.; Fanck, B.; Taute, T.; Dunnbier, U. Behaviour and redox sensitivity of antimicrobial residues during bank filtration. Chemosphere 2008, 73, 451-460. [CrossRef]

77. Jüttner, F. Efficacy of bank filtration for the removal of fragrance compounds and aromatic hydrocarbons. Water Sci. Technol. 1999, 40, 123-128. [CrossRef]

(C) 2018 by the authors. Licensee MDPI, Basel, Switzerland. This article is an open access article distributed under the terms and conditions of the Creative Commons Attribution (CC BY) license (http:/ / creativecommons.org/licenses/by/4.0/). 